\title{
ВЕНДСКИЙ ОСТРОВОДУЖНЫЙ ИНТРУЗИВНЫЙ МАГМАТИЗМ ОЗЕРНОЙ ЗОНЫ ЗАПАДНОЙ МОНГОЛИИ (геологические, геохронологические и петрохимические данные)
}

Руднев С. Н., Гибшер А. С., Семенова Д. В.

\begin{abstract}
Аннотация
На основе новых геохронологических данных по габброидным и плагиогранитоидным ассоциациям (Таван-Хаирханский, Восточно-Баянцаганский, Баян-Цаган-Ула, Тунгалагский, Три Холма и Шутхуинский массивы), расположенных среди вендских островодужных вулканогенных комплексов Озерной зоны Западной Монголии, обосновывается самостоятельный этап островодужного интрузивного магматизма вендского возраста (560-542 млн лет).

Геохронологические возрасты, полученные по ксеногенному циркону (716-559 млн лет) из габброидов и гранитоидов вендского возраста, указывают на широкий диапазон их формирования и различную природу источников. Предполагается несколько таких источников. К источнику первого типа относятся породы позднерифейской океанической коры Палеоазиатского океана, на которой позже закладывалась вендская островная дуга Озерной зоны. Об этом свидетельствуют возрастные даты ксеногенного циркона - 716, 658-642, 613-611 млн лет. К источнику второго (вероятно основного) типа относятся породы вендской островодужной коры Озерной зоны. На это указывает присутствие ксеногенного циркона с возрастами 583-559 млн лет, наблюдаемого во всех изученных интрузивных ассоциациях вендского возраста.
\end{abstract}

Ключевые слова: Центральная Азия, Озерная зона Западной Монголии, вендский интрузивный магматизм, геохронология, петрохимия.

\section{Ключевые слова:}




\title{
ВЕНДСКИЙ ОСТРОВОДУЖНЫЙ ИНТРУЗИВНЫЙ МАГМАТИЗМ \\ ОЗЕРНОЙ ЗОНЫ ЗАПАДНОЙ МОНГОЛИИ \\ (геологические, геохронологические и петрохимические данные)
}

\author{
С.Н. Руднев, А.С. Гибшер, Д.В. Семенова \\ Новосибирск, Россия, Институт геологии и минералогии СО РАН, \\ rudnev@igm.nsc.ru
}

\section{ВВЕДЕНИЕ}

Восстановление наиболее полной картины структуры островодужных систем, глобальных геологических образований Земной коры, является одной из актуальных задач геологической науки. Она имеет как теоретическое, так практическое значение. Взаимное дополнение информации по молодым и современным островодужным системам, изучаемым с поверхности, информацией по древним островодужным системам (вулканогенные и интрузивные комплексы), которая доступна благодаря глубокому эрозионному срезу, это основной путь решения такой задачи.

Одними из примеров расшифровки древних островодужных систем в ЦентральноАзиатском складчатом поясе является каледониды Восточной Тувы и Озерной зоны Западной Монголии. Результаты изучения вулканогенного и интрузивного магматизма раннекаледонского этапа развития Восточной Тувы (Таннуольская островная дуга), показали, что в ее структуре выделяется два этапа островодужного магматизма - вендский и раннекембрийский. Каждый из этих этапов фиксируется по формированию вулканогенных и вулканогенно-осадочных толщ и сопряженного с ними базитового и гранитоидного магматизма (572-562 и 534-518 млн лет) [Руднев и др., 2015, 2020; Монгуш и др., 2011; Вертов и др., 2019].

В Озерной зоне Западной Монголии, согласно данным геологических, геохронологических, петрогеохимических и изотопных исследований вулканогенных и осадочных комплексов, также как и в Восточной Туве, выделены два этапа островодужного магматизма - вендский ( 570 млн лет) и раннекембрийский ( 546 млн лет) [Дергунов, 1989; Коваленко и др., 2004; Ярмолюк и др., 2011; Ковач и др., 2011; Jian et al., 2010, 2014]. Установлено, что с раннекембрийским этапом тесно сопряжено проявление базитового и гранитоидного магматизма, проявленного в диапазоне возрастов 535-515 млн лет [Коваленко и др., 2004; Ярмолюк и др., 2011; Руднев и др., 2009, 2012, 2019]. Информации о времени и масштабах проявления островодужного интрузивного магматизма вендского этапа развития Озерной зоны еще очень мало. Исключение

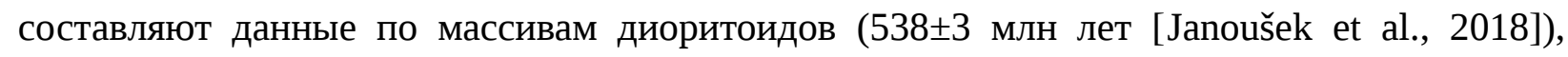
наблюдаемым среди вендских островодужных вулканитов в южных отрогах хр. Хан- 
Тайшири.

Комплексные исследования, проведенные в восточной части Озерной зоны, где широкое развитие имеют вендские островодужные вулканические комплексы, позволили получить новые данные по интрузивному магматизму (габброиды и гранитоиды) вендского возраста. Эти данные были получены на примере изучения габброидов ТаванХаирханского массива и гранитоидов Восточно-Баянцаганского, Баян-Цаган-Ула, Тунгалагский, Три Холма, Шутхуинского и Их-Замынского массивов, расположенные в восточной части Озерной зоны среди вендских островодужных вулканогенных и вулканогенно-осадочных отложений. По породам этих массивов выполнен широкий комплекс современных методов исследования вещества, результаты которых будут изложены с нескольких публикациях. В настоящей статье приведены данные по геологическому строению вышеупомянутых массивов, их петрохимическому составу и возрасту (U-Pb метод). При обсуждении U-Pb геохронологических данных, помимо магматического циркона, особое внимание уделено ксеногенному циркону, что позволило оценить не только время и последовательность формирования пород этих массивов и вероятную природу их источников, а также дать оценку источников питающих провинций Озерной зоны, на основе их корреляции с интрузивными комплексами прилегающих террейнов. Обсуждение геохимических и изотопно-геохимических особенностей пород этих массивов (Rb-Sr, Sm-Nd, Lu-Hf методы), авторы планируют провести в следующих публикациях.

\section{ГЕОЛОГИЧЕСКАЯ СИТУАЦИЯ}

Центрально-Азиатский складчатый пояс (ЦАСП) является крупной тектонической структурой Азиатского континента, в геологическом строении которого выделяется ряд складчатых поясов (позднерифейские, каледонские, герцинские и индосинийские) и расположенных внутри них микроконтинентов [Моссаковский и др., 1993; Диденко и др., 1994; Беличенко и др., 1994]. Наиболее ранние этапы формирования ЦАСП связываются с геологической историей развития Палеоазиатского океана. В качестве свидетельства существования древнего океана представлены, тектонически совмещенные позднерифейско-венд-раннекембрийские структурно-формационные комплексы, сформировавшиеся в пределах неопротерозойской океанической литосферы. Раскрытие Палеоазиатского океана связывают с позднерифейским расколом Лавразии на Сибирский и Лаврентийский кратоны и ряд микроконтинентов, начавшегося около 800 млн лет [Скляров и др., 2000; Ярмолюк, Коваленко, 2001; Ярмолюк и др., 2008; Torsvik et al., 1996; Meert, Torsvik, 2003]. В результате последующих процессов каледонского, герцинского и 
индосинийского тектогенеза эти комплексы, а также расположенные внутри них микроконтиненты, были причленены к Сибирскому кратону (рис. 1).

Один из таких «осколков» - Центрально-Азиатский микроконтинент (ЦАМ) [Гибшер, 2017] и особенно его юго-западное обрамление (в современных координатах) являются наиболее информативным объектом позднедокембрийско-раннепалеозойской геологической истории Центральной Азии. Несмотря на то, что современная структура ЦАМ и его обрамления представляет собой тектонический коллаж блоков, намечается отчетливое закономерное поясное омоложение структурно-формационных комплексов (см. рис. 1). Ближайший к Сибирскому кратону пояс представлен разобщенными блоками Канского, Гарганского, Тарбагатайского и Байдарикского массивов (2650 - 1830 млн лет) и более молодыми (но древнее 850 млн. лет) комплексами ювенильной и коровой природы [Козаков и др., 2011], которые можно считать фундаментом микроконтинента. Следующий пояс выполнен рифтогенными комплексами вулкано-плутонических и осадочных формаций кувайской (775 млн лет) [Watanabe et al., 1999], сархойской и дзабханской серий (803-773 млн лет) [Levashova et al., 2010] и прорывающих их щелочных гранитов ( 755 млн лет) [Ярмолюк и др., 2008]). Третий пояс (осадочный чехол) сложен карбонатными и терригенными окраинноморскими отложениями позднерифейско-раннекембрийского возраста. Четвертый пояс представлен вулкано-плутоническими и осадочными формациями океанической коры (Баян-Хонгорские офиолиты) Западной Монголии, отвечающие по составу океаническим лавовым плато - 665-636 млн лет [Ковач и др., 2005; Терентьева и др., 2010; Jian et al., 2010] и довендскими метабазитами ченсаирской толщи Западного Сангилена с геохимическими характеристиками базальтов N-MORB [Мокрушников, Гибшер, 2016]), а также венд-кембрийскими островодужными системами (вулканические дуги, преддуговые и задуговые окраинные бассейны) [Кузьмин и др., 1995; Хаин и др., 1995; Гибшер и др., 2001; Федотова, Хаин, 2002; Кузьмичев, 2004; Гордиенко, 2006; Монгуш и др., 2011; Ярмолюк и др., 2011; Руднев и др., 2009, 2012, 2013, 2015, 2019; Pfänder et al., 2002; Khain et al., 2003]. Протяженность четвертого пояса, начиная от г. Красноярска России до аймачного центра Баян-Хонгор Монголии превышает 2000 км, что сопоставимо с современными островодужными системами. Венд-кембрийские островодужные образования окаймляются позднекембрийско-раннеордовикским поясом мощных терригенных толщ турбидитовых подводных конусов выноса подножья континентального склона ЦАМ [Дергунов, 1989]. Формирование осадочного комплекса этого пояса связано с процессами аккреции и коллизии, начавшиеся в позднем кембрии.

Одним из фрагментов протяженного островодужного пояса является Озерная зона ранних каледонид. На востоке и юге (в современных координатах) Озерный 
островодужный пояс граничит с докембрийскими образованиями ЦАМ, на западе с поздними каледонидами Монгольского Алтая. В пределах этого островодужного пояса выполнен комплекс геологических и аналитических исследований, охватывающих различные по строению, составу и возрасту магматические и осадочные комплексы (офиолиты, вулканогенные и терригенные, гранитоиды и габброиды) [Изох и др., 1990, 1998; Хаин и др., 1995; Гибшер и др., 2001; Козаков и др., 2002; Коваленко и др., 2004; Гордиенко и др., 2006; Ярмолюк и др., 2006, 2011; Ковач и др., 2011; Руднев и др., 2009, 2012, 2013, 2019; Jian et al., 2014; Khukhuudei et al., 2020]. Данные геологических и геохронологических исследований показали, что заложение этого пояса ограничено «снизу» офиолитами древней океанической коры, возраст которой фиксируется по плагиогранитам офиолитовых комплексов хребтов Дариби и Хан-Тайшири - 573-560 млн лет [Гибшер и др., 2001; Khain et al., 2001; Jian et al., 2014]. Островодужный магматизм в Озерной зоне приходится на временной интервал 570-515 млн лет [Коваленко и др., 2004; Ярмолюк и др., 2011; Руднев и др., 2009, 2012, 2019; Buriánek et al., 2017; Janoušek et al., 2018]. Столь длительное существование пояса (около 60 млн лет) предполагало более сложную природу его формирования, а именно, сочетание, как минимум, двух островодужных систем - вендской и раннекембрийской. В позднем кембрии-ордовике, в результате аккреционных процессов венд-раннекембрийские островодужные вулканические комплексы и подстилающие их офиолиты были обдуцированны на докембрийские образования ЦАМ.

О наличии вендской и раннекембрийской островных систем в структуре Озерной зоны (включая весь комплекс вулканогенных и терригенно-осадочных отложений) высказывались многие исследователи. В частности, об этом упоминается в работах А.Б. Дергунова [Дергунов, 1989], а также Б.А.Самозванцева с соавторами [Samozvantsev et al., 1981] при составлении геологических карт масштаба 1:200 000 в этом регионе. Наиболее полное и обоснованное выделение вендской и раннекембрийской островных дуг в этом регионе было сделано В.И. Коваленко с соавторами [Коваленко и др., 2004], В.В. Ярмолюком с соавторами [Ярмолюк и др., 2011] и В.П. Ковачем с соавторами [Ковач и др., 2011] при изучении вещественного состава, геохимических и изотопно-геохимических характеристик пород и их возраста, участвующих в строении вулканогенных и осадочных разрезов в осевой и западной части Озерной зоны (хр. Сейр, горные массивы Гэлбен-Ула и Халдзан-Бурэгтэй,). Этими исследователями были выделены базальт-андезитовый ( 570 млн лет) и андезитовый ( 546 млн лет) комплексы, со всем набором осадочных и терригенных пород (комплексы аккреционных призм), относящиеся к двум внутриокеаническим островным дугам, формировавшихся в разных частях 
палеоокеанического бассейна на некотором удалении друг от друга, в том числе, от областей размыва и сноса пород ЦАМ. Несколько позднее, к аналогичному выводу пришли другие исследователи [Jian et al., 2014; Khukhuudei et al., 2020], при изучении строения, состава и характера распространения вулканогенных и терригенно-осадочных отложений на северо-западе хр. Дариби и в других частях Озерной зоны. В современных координатах эти две островодужные системы разделены межгорной впадиной великих озер Монголии: вендская - на востоке, раннекембрийская - на западе.

Вместе с тем, вендская островодужная система Озерной зоны наиболее детально была изучена на южных склонах хр. Хан-Тайшири и хр. Улан-Шанда. На рис. 2 иллюстрируется принципиальная модель тектоно-стратиграфического разреза океанической коры и перекрывающих ее вендских островодужных вулканитов. Достаточно точно определен временной интервал развития островодужной системы от заложения в начале венда (моложе 568 млн лет - плагиограниты офиолитовых ассоциаций хр. Хан-Тайшири и Дариюи) до завершения в томмотское время раннего кембрия (530-529 млн лет - раннетоммотская мелкораковинная фауна) [Гибшер и др., 2001; Переляев и др., 2004; Переляев, Гибшер, 2005; Gibsher et al., 2006]. Кроме того, в центральной части хр. Дариби, согласно данным А. Кренера с соавторами [Kröner et al., 2001], наблюдаются горизонты конгломератов, которые перекрывают вендские офиолиты и вулканогенные толщи в районе хр. Дариби. В составе этих конгломератов отмечается галька риолитов, которая по вещественному составу идентична риолитам, описанных в составе верхней части разреза базальт-андезитового комплекса вендского возраста. Возраст риолитов из гальки конгломератового горизонта, по данным U-Pb изотопных исследований циркона, составляет 540 млн лет [Kröner et al., 2001], что ограничивает сверху время формирования вендской островодужной системы. Важно отметить, что с формированием вендской островодужной системы тесно взаимосвязано проявление гранитоидного и базитового магматизма. Ниже приводятся результаты геологических, геохронологических и петрохимических исследований гранитоидных и габброидных массивов (ВосточноБаянцаганский, Баян-Цаган-Ула, Тунгалагский, Три Холма, Шутхуинский и ИхЗамынский), расположенных среди вендских островодужных вулканогенных образований Озерной зоны, опоясывающих (в современных координатах) с запада и юга ЦАМ.

\section{МЕТОДЫ ИССЛЕДОВАНИЯ}

Содержания петрогенных элементов определены на рентгенофлюоресцентном спектрометре ARL-9900 XL в ЦКП многоэлементных и изотопных исследований CO PAH (Новосибирск, Россия, аналитики - Н.Г. Карманова, А.Н. Торяник). 
U-Pb изотопные исследования циркона выполнены методом LA-SF-ICP-MS в ЦКП многоэлементных и изотопных исследований СО РАН (Новосибирск, Россия) и в Центре изотопных исследований Всесоюзного геологического института им. А.П. Карпинского (ВСЕГЕИ, Санкт-Петербург, Россия). В ЦКП многоэлементных и изотопных исследований СО РАН аналитические исследования проводились по единичным зернам циркона на массспектрометре высокого разрешения с индуктивно связанной плазмой Element XR (Thermo Finnigan) по методике описанной в работе [Хубанов и др., 2016]. В Центре изотопных исследований ВСЕГЕИ U-Pb изотопные исследования циркона выполнены по единичным зернам на ионном микрозонде SHRIMP-II (аналитики Е.Н. Лепехина, А.Н. Ларионов) по методике описанной в работе [Руднев и др., 2019].

\section{ГЕОЛОГИЧЕСКОЕ СТРОЕНИЕ МАССИВОВ И ИХ ВОЗРАСТЫ}

Среди вендских вулканогенных и вулканогенно-осадочных отложений Озерной СФЗ обнажается серия мелких интрузий гранитоидов и габброидов, которые наблюдаются либо в виде отдельных удаленных друг от друга массивов, либо сближенных в составе магматических ареалов (рис. 3). Названия ареалов и отдельных массивов даны условно по их географическому местоположению.

Баянцаганский ареал интрузивного магматизма. В его составе выделяется несколько интрузивных массивов гранитоидного и габброидного состава, расположенных в осевой части хр. Баян-Цаган-Нуру. Они сложены преимущественно тоналитами и плагиогранитами массива Три Холма, Восточно-Баянцаганского, Баян-Цаган-Улинского и Баян-Цаганского массивов (см. рис. 3). В этом ареале также отмечается несколько мелких массивов и штоков плагиогранитоидного состава кембро-ордовикского возраста, описанных в работах [Руднев и др., 2012]. Габброидные ассоциации хиргиснурского перидотит-пироксенит-габброноритового комплекса представлены в составе ТаванХаирханского и Баян-Цаганского массивов и других мелких интрузиях. Вещественный состав, возраст и строение Баян-Цаганского массива рассмотрены в работе [Изох и др., 1990, 1998; Хаин и др., 1995].

Массив Три Холма. На современном эрозионном срезе выходы этого массива обнажаются среди четвертичных отложений, а по данным бурения они прорывают вулканиты вендского возраста. В составе массива выделяются среднезернистые амфиболовые кварцевые диориты, средне-крупнозернистые биотит-амфиболовые тоналиты и плагиограниты. Значение возраста, полученное ранее по циркону из

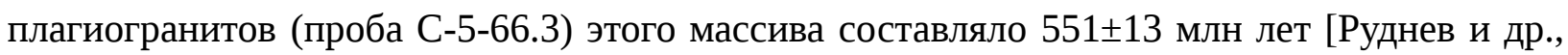
2012]. Однако более детальные исследования показали, что в аналитические расчеты 
попала часть зерен, имеющая ксеногенную природу (рис. 4). Пересмотр полученных изотопных данных, позволил уточнить его возраст, равный $544 \pm 7$ млн лет (рис. 5). Значения возрастов, полученные по двум зернам ксеногенного циркона, равны $580 \pm 16$ и $716 \pm 18$ млн лет.

Таван-Хаирханский массив находится в районе одноименной горы (1325 м). Основной объем массива слагают среднезернистые амфиболовые лейкогаббро. Для определения возраста пород этого массива была отобрана проба (РМ-35/1-07) среднезернистых амфиболовых лейкогаббро. Конкордантное значение возраста,

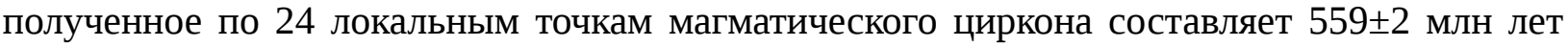
(см. рис. 4, 5; табл. S1). В монофракции наблюдалось 4 зерна ксеногенного циркона, имеющие ярко выраженную магматическую зональность. Конкордантное значение

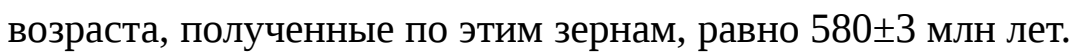

Восточно-Баянцаганский массив имеет изогнутую форму, площадью около 5 кв. км. В строении массива принимают участие массивные средне-крупнозернистые биотитамфиболовые плагиограниты, жильная серия - дайки диабазов. U-Pb изотопные исследования, проведенные по 19 зернам магматического циркона (проба РМ-10-47)

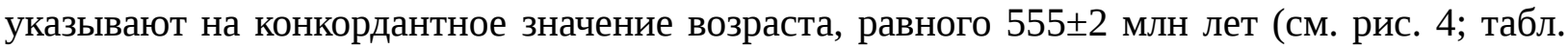
S1). Во внутренних частя магматического циркона отмечается многочисленные реликты ксеногенного циркона (13 зерен, см. рис. 4). По 9 зернам получено конкордантное значение возраста, равное $574 \pm 2$ млн лет, а по 4 зернам - 613 $\pm 5,611 \pm 5,658 \pm 6$ и $642 \pm 6$ млн лет (см. рис. 5).

Массив Баян-Цаган-Ула, площадью около 4.5 кв. км, расположен в районе одноименной горы $(1840$ м). В составе массива выделяются среднезернистые биотитамфиболовые кварцевые диориты, мелко-среднезернистые и неравномернозернистые тоналит-порфиры (последние преобладают). Изотопные исследования, проведенные по магматическому циркону (проба РM-44/1-07, табл. S2 ) свидетельствуют о конкордантном

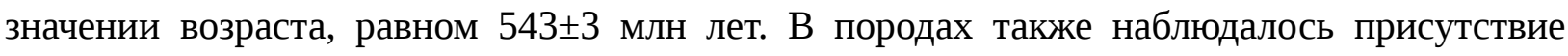
единичных зерен ксеногенного циркона (см. рис. 4), конкордантное значение возраста

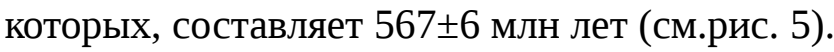

Дарибский ареал интрузивного магматизма. В пределах ареала выделяется несколько интрузивных массивов гранитоидного и габброидного состава, расположенных в осевой и южной частях хр. Дариби. Вещественный состав, геологическое строение и возраст этих массивов рассмотрен в работах [Хаин и др., 1995; Козаков и др., 2002; Dijkstra et al., 2006; Jian et al., 2010, 2014]. В настоящей работе приведены результаты исследования пород Тунгалагского и Их-Замынского массивов, расположенных в южных 
отрогах этого хребта (см. рис. 3).

Тунгалагский массив расположен приблизительно в 30 км на север от сомона Дарив (южный) в левом борту урочища Тунгалак. Он имеет удлиненную форму, площадью около 20 кв. км. В составе массива выделяется две плагиогранитные ассоциации, образующие отдельные интрузивные ритмы. Породы плагиогранитоидной ассоциации раннего ритма развиты преимущественно в южной и западной частях массива. В строении этой ассоциации выделяется несколько интрузивных фаз: 1 фаза (главная) - гнейсовидные крупно-среднезернистые амфиболовые плагиограниты и лейкоплагиограниты, 2 фаза гнейсовидные средне-мелкозернистые амфиболовые лейкоплагиограниты, жильная серия - дайки мелко- и среднезернистых амфиболовых лейкоплагиогранитов и долеритов.

Породы плагиогранитоидной ассоциации позднего ритма слагают основной объем Тунгалакского массива ( 70 \%). Они обнажаются в северной и восточной его частях. По минералого-петрографическому составу породы этого ритма практически не отличаются от пород раннего ритма, за исключением их более крупнозернистого строения и отсутствия гнейсовидных структур. В составе ритма выделяются две интрузивные фазы: 1 фаза (главная) - крупнозернистые массивные порфировидные амфиболовые плагиограниты и лейкоплагиограниты, 2 фаза - массивные среднезернистые амфиболовые плагиограниты и лейкоплагиограниты. Жильная серия - дайки и жилы среднезернистых амфиболовых плагиогранитов и долеритов.

Для определения возраста плагиогранитов раннего и позднего ритмов были отобраны монофракции циркона (проба РМ-7-16 и проба РM-8-15, соответственно, см. рис.4). Значения возрастов, полученные по магматическому циркону из пород этого

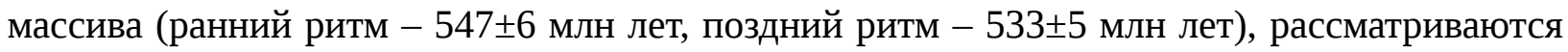
пока как предварительные, из за малого объема достоверных аналитических данных (см. рис. 5, табл. S1). Значения возрастов ксеногенного циркона, наблюдаемого в породах этих ассоциаций, составляют $566 \pm 5$ и $565 \pm 9$ млн лет (соответственно).

Их-Замынский массив расположен в $\sim 7$ км к северо-востоку от сомона Дарив (южный) в южных отрогах хр. Дариби. Массив имеет удлиненную в восточном направлении форму (7x1.5 км). На севере и западе породами массива прорываются вендские вулканогенные отложения и надвинутые на них раннекембрийские вулканогенно-осадочные отложения (реликты), а на юге - по тектоническому разлому контактируют с гранито-гнейсами ЦАМ (см. рис. 3). Интрузив сложен массивными порфировидными крупнозернистыми биотит-амфиболовыми двуполевошпатовыми гранитами, среди которых иногда встречаются ксенолиты амфиболовых кварцевых диоритов. Завершают формирование массива жилы пегматоидных и аплитовидных 
биотитовых-амфиболовых гранитов и дайки лампрофиров. Для определения возраста была выделена монофракция циркона из крупнозернистых двуполевошпатовых гранитов центральной части массива (проба РМ-13А-16). Изотопные исследования магматического циркона, проведенные по цирконам различными U-Pb изотопными методами (см. табл. S1, S2), дали хорошую сходимость результатов. Конкордантное значение возраста (см. рис. 5;

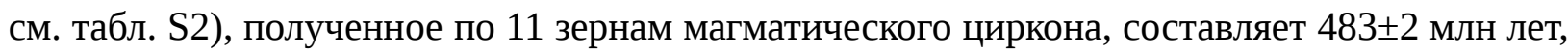

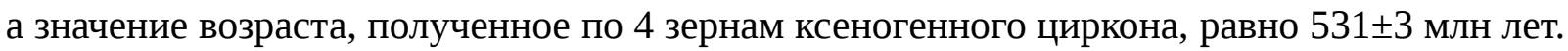

Дзабхан-Хунгуйский ареал интрузивного магматизма. Ареал расположен в северной части Озерной зоны, в междуречье Дзабхан-Гол и Хунгуй-Гол. В его составе выделяется серия массивов плагиогранитного, диоритоидного и габброидного состава. Авторами статьи был изучен Шутхуинский массив (площадью 4 кв. км), расположенный приблизительно в 50 км на запад от самона Ургамал, в районе г. Шутхуин-Оэрхг-Ула (1397 м). В строении массива принимают участие средне-крупнозернистые биотит-амфиболовые кварцевые диориты. Конкордантное значение возраста, полученное по магматическому

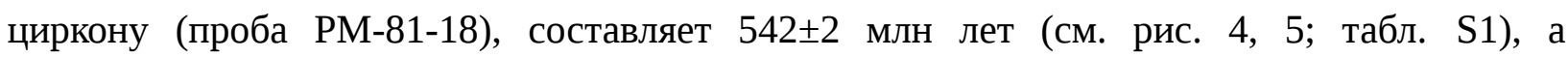
средневзвешенное значение возраста (по $\left.{ }^{206} \mathrm{~Pb} /{ }^{238} \mathrm{U}\right)$ ксеногенного циркона $-566 \pm 6$ млн лет.

\section{ПЕТРОХИМИЯ}

По петрохимическим характеристикам породы массивов Три Холма, Баян-ЦаганУла, Шутхуинского отвечают гранитоидам известково-щелочной серии (І-тип) нормального ряда. На диаграмме $\mathrm{SiO}_{2}-\mathrm{K}_{2} \mathrm{O}$ (рис. 6, табл. S3) они занимают промежуточное положение между областью составов гранитоидов с низкими и умеренными содержаниями $\mathrm{K}_{2} \mathrm{O}$. Для всех породных разновидностей характерно резкое преобладание содержаний $\mathrm{Na}_{2} \mathrm{O}$ над $\mathrm{K}_{2} \mathrm{O}$. На диаграмме A/CNK-A/NK (индекс Шенда 0.63-1.05) точки состава располагаются в полях гранитоидов метаглиноземистого типа, а на диаграмме $\mathrm{SiO}_{2}-\mathrm{FeO}^{*} /(\mathrm{FeO}+\mathrm{MgO})$ отвечают гранитоидам магнезиального типа. На диаграмме в координатах Ab-An-Or, породы этих массивов образуют эволюционный тренд в области состава пород тоналит-трондьемитовой серии.

Плагиограниты Тунгалагского и Восточно-Баянцаганского массивов, по сравнению с вышеописанными плагиогранитоидами, характеризуются более низкими содержаниями $\mathrm{Al}_{2} \mathrm{O}_{3}$ (11.67-13.86 мас. \%). По содержанию $\mathrm{K}_{2} \mathrm{O}$ (0.32-0.97 мас. \%), как видно из диаграммы $\mathrm{SiO}_{2}-\mathrm{K}_{2} \mathrm{O}$, попадают в поле низкокалиевых гранитоидов. На диаграмме $\mathrm{SiO}_{2}-$ $\mathrm{FeO} * /(\mathrm{FeO}+\mathrm{MgO})$ они располагаются в области пород железистого и магмнезиального типа. По этим петрогеохимическим характеристикам, породы этих массивов занимают промежуточное положение между гранитоидами толеитовой и известково-щелочной 
серий.

Двуполевошпатовые граниты Их-Замынского массива, в отличие от пород выше описанных массивов, характеризуются более высокими суммарными содержаниями щелочей и $\mathrm{K}_{2} \mathrm{O}$ (2.84-3.50 мас. \%) и на диаграмме $\mathrm{SiO}_{2}-\mathrm{Na} 2 \mathrm{O}+\mathrm{K}_{2} \mathrm{O}$ тяготеют к гранитоидам известково-щелочной серии повышенной калиевости. На диаграммах A/CNK-A/NK (индекс Шенда 1.04-1.16) они занимают промежуточное положение между породами метаглиноземистого и высокоглиноземистого типов.

Лейкогаббро Таван-Хаирханском массива по петрохимическому составу попадают в поле основных пород нормального ряда. Породы характеризуются широкими содержаниями окислов и, в целом, составляют: $\mathrm{SiO}_{2}$ (46.7-52.3 мас. \%), $\mathrm{Na}_{2} \mathrm{O}+\mathrm{K}_{2} \mathrm{O}$ (1.8-4.0 мас. \%), $\mathrm{Al}_{2} \mathrm{O}_{3}$ (20.9-22.7 мас. \%), а также устойчивыми и умеренными содержаниями $\mathrm{TiO}_{2}$ (0.67-0.98 мас. \%) и магнезиальность (22-31\%). По этим петрохимическим параметрам они отвечают габброидам высокоглиноземистого низкотитанистого типа [Изох и др., 1998].

\section{ОБСУЖДЕНИЕ РЕЗУЛЬТАТОВ}

\section{Стадии формирования интрузивного магматизма вендской островной дуги}

Озерной зоны . Результаты U-Pb изотопных исследований магматического циркона, проведенные для различных по минералого-петрографическому и петрогеохимическому составам породным ассоциаций (Три Холма, Таван-Хаирханский, ВосточноБаянцаганский, Баян-Цаган-Ула, Тунгалагский, Шутхуинский и Их-Замынский массивы), позволили установить временной интервал проявления вендского интрузивного магматизма 560-540 млн лет в Озерной СФ3 (см. рис. 5). В этом возрастном диапазоне формировались плагиогранитоиды и габброиды различных пертохимических серий. Условно их можно разделить на две группы, которые отражают разные стадии проявления интрузивного магматизма.

K первой группе (560-555 млн лет) относятся габброиды Таван-Хаирханского

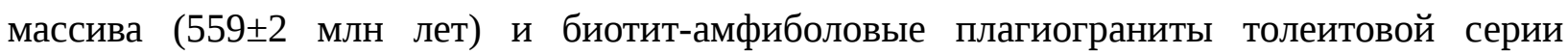

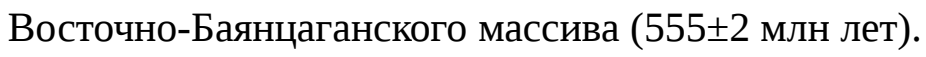

Во вторую группу (547-544 млн лет) объединяются тоналит-плагиогранитные ассоциации известково-щелочной и толеитовой серии, которые представлены в массивах

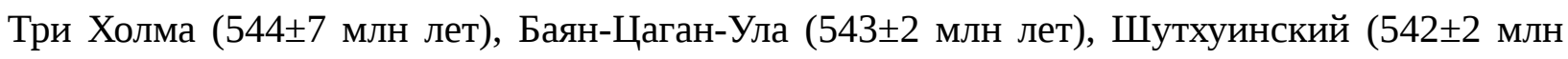
лет) и Тунгалагский (547 млн лет, ранний ритм). Близкие им по возрасту являются мелкие

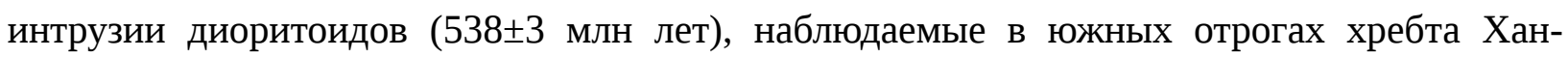
Тайшири [Janoušek et al., 2018]. Плагиограниты позднего ритма Тунгалагского массива 
(533 \pm 5 млн лет) пока не рассматриваются, вследствие недостаточного количества геохронологических данных (см. выше).

Известково-щелочные биотит-амфиболовые двуполевошпатовые граниты Их-

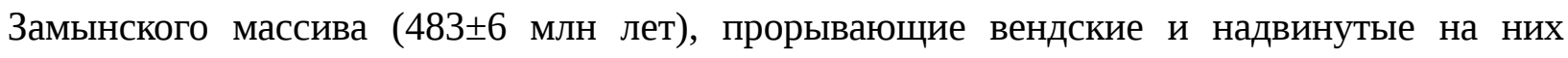
раннекембрийские (фрагменты) островодужные вулканиты и тектонически контактирующие с докембрийскими образованиями ЦАМ, к вендскому островодужному интрузивному магматизму не имеют отношения. Их формирование, связано с аккреционно-коллизионными процессами тектогенеза, проявившиеся в позднем кембрии ордовике в стуктурах Озерной СФЗ [Ярмолюк и др., 2011; Руднев и др., 2009, 2012, 2019]..

U-Pb изотопные исследования ксеногенного циркона. Геохронологические исследования ксеногенного циркона из гранитоидных и габброидных ассоциаций вышеупомянутых массивов показали, что их возраст варьирует в широком диапазоне от 716 до 531 млн лет (см. табл. S1, S2; см. рис. 5). Условно их можно разделить на пять возрастных групп.

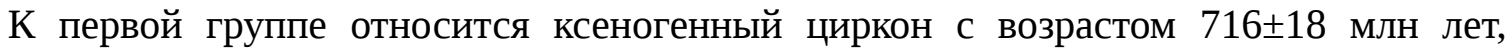
который был зафиксирован в плагиогранитоидах массива Три Холма. На сопредельных с Озерной зоной территориях, аналогичные значения возраста установлены для

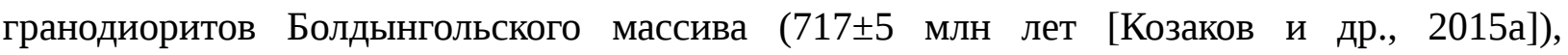
прорывающие плагиогнейсы свиты будун , рассматриваемые как типовые образования фундамента ЦАМ (район аймака Улиастай).

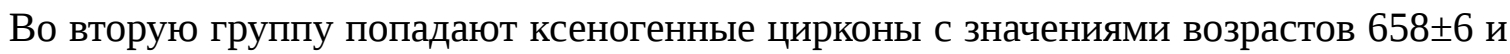
$642 \pm 6$ млн лет. Они наблюдались только в плагиогранитах Восточно-Баянцаганского массива. В сопредельных с Озерной зоной регионах близкие значения возрастов фиксируются для пород Баянхонгорского офиолитового пояса, отвечающих по составу

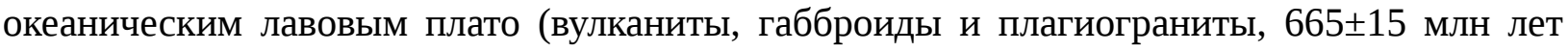
[Ковач и др., 2005]), имеющие Nd изотопные характеристики, близкие к деплетированной мантии $\left(\varepsilon_{\mathrm{Nd}}+12 \ldots+8\right.$ [Терентьева и др., 2010]).

В третью группу объединяются два зерна ксеногенного циркона из плагиогранитов Восточно-Баянцаганского массива с возрастами $613 \pm 5$ и 611 5 млн лет. На сопредельных территориях наиболее близкое значение возраста установлено для метагабброидов

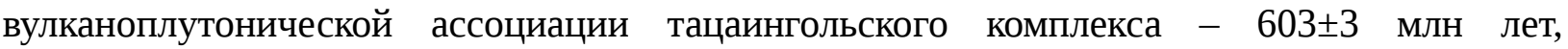
расположенного в зоне сочленения Тацаингольского блока и Баянхонгорской офиолитовой зоны [Козаков и др., 2015б]). 
Авторы статьи, исходя из выше упомянутых геохронологических возрастов и ранее опубликованных возрастных данных предшественников предполагают, что, вероятнее всего, ксеногенные цирконы этих трех групп отвечают времени становления разных по вещественному составу интрузивных комплексов, проявившиеся в процессе формирования позднерифейской океанической коры Палеоазиатского океана (800-600 млн лет), на которой позднее закладывались вендская и раннекембрийская островные дуги.

В четвертую (основную) группу попадают ксеногенные цирконы, которые встречаются практически во всех изученных массивах. Полученные по ним геохронологические данные указывают на возрастной диапазон 583-559 млн лет (см. рис. 5, см. табл. S1, S2), что, в целом, согласуется с временем формирования офиолитовых ассоциаций хр. Дариби и Хан-Тайшири (573-560 млн лет [Гибшер и др., 2001; Khain et al., 2001; Jian et al., 2014]) и вулканогенных комплексов вендской островодужной системы Озерной зоны ( 570 млн лет [Ярмолюк и др., 2011]).

В пятую группу объединяются ксеногенные цирконы с диапазоном возрастов 537526 млн лет, наблюдаемые в кембро-ордовикских двуполевошпатовых гранитах ИхЗамынского массива (см. рис. 5; см. табл. S1). Вероятнее всего, они были заимствованы гранитным расплавом из осадков, образованных путем разрушения пород раннекембрийского возраста (гранитоиды и вулканиты островодужного типа) [Ярмолюк и др., 2011; Руднев и др., 2009, 2012, 2019].

Важно отметить, что ксеногенные цирконы с возрастами древнее 716 млн лет в изученных гранитоидах и габброидах венского возраста Озерной зоны не встречаются. Это свидетельствует о том, что формирование исходных расплавов вендских интрузивных комплексов происходило на значительном расстоянии от областей сноса и размыва докембрийских образований ЦАМ.

\section{ЗАКЛЮЧЕНИЕ}

1. Геологические и геохронологические исследования габброидных и плагиогранитоидных ассоциаций, расположенных среди вулканогенных образований вендской островной дуги Озерной зоны Западной Монголии, показали, что их формирование прослеживается интервале возрастов от 559 до 442 млн лет. В этом возрастном диапазоне условно можно выделить две стадии интрузивного магматизма, отражающие разные этапы развития островной дуги: ранняя стадия (560-555 млн лет) габброиды и плагиограниты (Таван-Хаирханский и Восточно-Баянцаганский массивы) и заключительная стадия (547-542 млн лет) - кварцевые дириты, тоналиты и плагиограниты (массивы Три Холма, Баян-Цаган-Ула, Шутхуинский, Тунгалагский). 
По петрохимическому составу породы изученных плагиогранитоидных ассоциаций, участвующие в строении этих массивов, относятся к толеитовой и известково-щелочной серии.

2. Ксеногенные цирконы, наблюдаемые в породах изученных массивов, имеют широкий возрастной диапазон формирования от 718 до 559 млн лет. Намечается пять возрастных групп ксеногенного циркона ( 716, 658-642, 613-611, 583-559, 537-526 млн лет), отражающие различные источники вещества (вероятнее всего, в виде осадков), которые дополнительно вовлекались в плавление при формировании исходных расплавов пород изученных массивов. Первые три группы ксеногенного циркона, вероятнее всего, указывают на возрасты интрузивных комплексов, становление которых происходило на разных стадиях формирования океанической коры Палеоазиатского океана (800-600 млн лет). Ксеногенные цирконы четвертой группы (583-559 млн лет), наблюдаемые во всех изученных интрузивных островодужных ассоциациях вендского возраста Озерной зоны, не отличаются по возрасту от времени формирования вмещающих вендских вулканических комплексов ( 570 млн лет) и подстилающих их офиолитов хр. Дариби и Хан-Тайшири (573-560 млн лет), что может указывать как на островодужную, так и океаническую природу источников исходных расплавов для пород этих массивов. Ксеногенные цирконы пятой группы (537-526 млн лет), присутствующие в кембро-

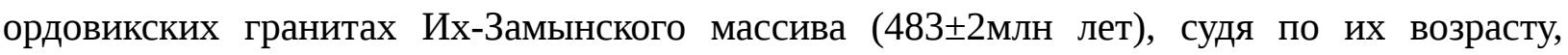
вероятнее всего, были заимствованы расплавом из осадков, образованных за счет разрушения и смыва пород раннекембрийского возраста (островодужные вулканогенные и интрузивные комплексы).

3. Отсутствие в вендских плагиогранитоидах и габброидах Озерной зоны ксеногенного циркона древнее 716 млн лет указывают на то, что докембрийские образования ЦАМ не оказывали какого-либо влияния на составы исходных расплавов вендских интрузивных комплексов и на удаленность вендской островной дуги Озерной зоны от областей сноса и размыва древних докембрийских блоков.

Благодарности. Авторы выражают глубокую благодарность рецензентам Н.Н. Круку и Е.В. Склярову за замечания, ценные советы и рекомендации, А.Э. Изоху за плодотворные дискуссии в ходе работы над рукописью статьи, Р.А. Шелепаеву, Я.Ю. Шелепову за помощь в проведении экспедиционных работ, Е.А. Крук (ИГМ СО РАН, Новосибирск) за обработку каменного и графического материалов, а также Н.Г. Кармановой, А.Н. Торянику (ЦКП многоэлементных и изотопных исследований СО РАН, Новосибирск), Е.Н. Лепехиной, А.Н. Ларионову, Н.В. Родионову, Н.Г. Бережной, А.В. 
Антонову (ВСЕГЕИ, Санкт-Петербург), принимавших участие в аналитических исследованиях.

Работа выполнена по государственному заданию ИГМ СО РАН и при финансовой поддержке РФФИ (грант 18-05-00105).

\section{ЛИТЕРАТУРА}

Беличенко В.Г., Скляров Е.В., Добрецов Н.Л., Томуртогоо О. Геодинамическая карта Палеоазиатского океана. Восточный сегмент // Геология и геофизика, 1994, т. 35 (78), c. 29-40.

Ветров Е.В., Черных А.И.,Бабин Г.А. Раннепалеозойский гранитоидный магматизм Восточно-Таннуольского сектора Тувмнского магматического пояса: геодинамическая позиция, возраст и металлогения // Геология и геофизика, 2019, т. 60 (5), c. $641-665$.

Гибшер А.С., Хаин Е.В., Котов А.Б., Сальникова Е.Б., Козаков И.К., Ковач В.П., Яковлева С.3., Федосеенко А.М. Поздневендский возраст хантайширкого офиолитового комплекса Западной Монголии // Геология и геофизика, 2001, т. 42 (8), с. 1179-1185.

Гибшер А.С. Микроконтинент Центрально-Азиатского подвижного пояса. // Геодинамическая эволюция Центрально-Азиатского подвижного пояса (от океана к континенту). Иркутск: Изд-во ИЗК СО РАН, 2017, выпуск 15, с. 49-51.

Гордиенко И.В. Геодинамическая эволюция поздних байкалид и палеозоид складчатого обрамления Сибирской платформы // Геология и геофизика, 2006, т. 47 (1), с. $53-70$.

Дергунов А.Б. Каледониды Центральной Азии. 1989, М., Наука, 192 с.

Диденко А.Н., Моссаковский А.А., Печерский Д.М., Руженцев С.В., Самыгин С.Г., Хераскова Т.Н. Геодинамика палеозойских океановЦентральной Азии // Геология и геофизика, 94, т. 35 (7-8), с. 59-76.

Изох А.Э., Поляков Г.В., Кривенко А.П., Богнибов В.И., Баярбилэг Л. Габброидные формации Западной Монголии. Новосибирск: Изд-во Наука, СО РАН, 1990. 269 c.

Изох А.Э., Поляков Г.В., Гибшер А.С., Балыкин П.А., Журавлев Д.З., Пархоменко В.А. Высокоглиноземистые расслоенные габброиды Центрально-Азиатского складчатого пояса: геохимические особенности, Sm-Nd изотопный возраст и геодинамические условия формирования // Геология и геофизика, 1998, т. 39 (11), с. 15651577. 
Коваленко В.И., Ярмолюк В.В., Сальникова Е.Б., Карташов П.М., Ковач В.П., Козаков И.К., Козловский А.М., Котов А.Б., Пономарчук В.А., Листратова Е.Н., Яковлева С.3. Халдзан-Бурегтейский массив щелочных и редкометальных магматических пород: строение, геохронология и геодинамическое положение в каледонидах Западной Монголии // Петрология, 2004, т. 12 (5), с. 467-494.

Ковач В.П., Ярмолюк В.В., Козаков И.К., Терентьева Л.Б., Лебедев В.И., Коваленко В.И. Магматизм и геодинамика ранних стадий образования Палео-Азиатского океана: геологические и геохимические данные офиолитов Баян-Хонгорской зоны // Доклады АН, 2005, т. 404 (2), с. 229-234.

Ковач В.П., Ярмолюк В.В., Коваленко В.И., Козловский А.М., Котов А.Б., Терентьева Л.Б. Состав, источники и механизмы формирования континентальной коры Озерной зоны каледонид Центральной Азии. II. Геохимические и Nd-изотопные данные // Петрология, 2011, т. 19, № 3, с. 1-29.

Козаков И.К., Сальникова Е.Б., Хаин Е.В., Ковач В.П., Бережная Н.Г., Яковлева С.3., Плоткина Ю.В. Этапы и тектонические обстановки формирования комплексов ранних каледонид Озерной зоны Монголии: результаты U-Pb и Sm-Nd изотопных исследований // Геотектоника, 2002, № 2, с. 80-92.

Козаков И.К., Козловский А.М., Ярмолюк В.В., Ковач В. П., Бибикова Е. В., Кирнозова Т. И., Плоткина Ю. В., Загорная Н. Ю., Фугзан М. М., Эрдэнэжаргал Ч., Лебедев В. И., Энжин $\boldsymbol{\Gamma}$. Кристаллические комплексы Тарбагатайского блока раннекаледонского супертеррейна Центральной Азии. // Петрология, 2011, т. 19, № 4, с. 445-464.

Козаков И.К., Кирнозова Т.И., Ковач В.П., Терентьева Л.Б., Толмачева Е.В., Фугзан М.М., Эрдэнэжаргал Ч. Позднерифейский возраст кристаллического фундамента карбонатного чехла Дзабханского микроконтинента // Стратиграфия. Геологическая корреляция, 2015а, т. 23 (3), с. 3-12.

Козаков И.К., Сальникова Е.Б., Ковач В.П., Яковлева С.З., Анисимова И.В., Козловский А.М., Плоткина Ю.В., Федосеенко А.М., Эрдэнэжаргал Ч. Основные этапы развития и геодинамическая обстановка формирования Южно-Хангайского метаморфического пояса Центральной Азии // Петрология, 2015б, т. 23 (4), с. 339-362.

Кузьмин М.И., Гордиенко И.В. Альмухамедов А.И, Антипин В.С., Баянов В.Д., Филимонов А.В. Палеоокеанические комплексы Джидинской зоны каледонид (ЮгоЗападное Забайкалье) // Геология и геофизика, 1995, т. 36 (1), с. 3-18. 
Кузьмичев А.Б. Тектоническая история Тувино-Монгольского массива: раннебайкальский, позднебайкальский и раннекаледонский этапы. М.: Пробел-2000, 2004. 192c.

Мокрушников В.П., Гибшер А.С. Природа вендских базальтоидов чонсаирской свиты Агардакской геосутуры Юго-Восточной Тувы. // Геодинамическая эволюция Центрально-Азиатского подвижного пояса (от океана к континенту), 2016, выпуск 14, с. 202-203.

Монгуш А.А., Лебедев В.И., Ковач В.П., Сальникова Е.Б., Дружкова Е.К., Яковлева С.З., Плоткина Ю.В., Загорская Н.Ю., Травин А.В., Серов П.А. Тектономагматическая эволюция структурно-вещественных комплексов Таннуольской зоны Тувы в позднем венде-раннем кембрии (на основе геохимических, Nd изотопных и геохронологических данных) // Геология и геофизика, 2011, т. 52, № 5, с. 649-665.

Моссаковский А.А., Руженцев С.В., Самыгин С.Г., Хераскова Т.Н. ЦентральноАзиатский складчатый пояс: геодинамическая эволюция история формирования // Геотектоника, 1993, № 6, с. 3-33.

Переляев В.И., Гибшер А.С., Рябинин А.Б. Эффузивно-дайковая серия офиолитовой ассоциации каньона р. Сувра-Гол (хр. Хан-Тайшири, Монголия). // Геодинамическая эволюция Центрально-Азиатского подвижного пояса (от океана к континенту), 2004, выпуск 2, с. 52-54.

Переляев В.И., Гибшер А.С. Разрез океанической коры венд-раннекембрийского окраинного бассейна Палеоазиатского океана (каньон Сувра-Гол, южный склон хр. ХанТайшири, Западная Монголия). // Геодинамическая эволюция Центрально-Азиатского подвижного пояса (от океана к континенту), 2005, выпуск 3, с. 68-70.

Руднев С.Н., Изох А.Э., Ковач В.П., Шелепаев Р.А., Терентьева Л.Б. Возраст, состав, источники и геодинамические условия формирования гранитоидов северной части Озерной зоны Западной Монголии: механизмы роста палеозойской континентальной коры // Петрология, 2009, т. 17 (5), с. 470-508.

Руднев С.Н., Изох А.Э., Борисенко А.С., Шелепаев Р.А., Orihashi Y., Лобанов K.B., Вишневский А.В. Раннепалеозойский гранитоидный магматизм Бумбатхаирханского ареала Озерной зоны Западной Монголии (геологические, петрохимические и геохронологические данные) // Геология и геофизика, 2012, т. 53 (5), с. 557-578.

Руднев С.Н., Ковач В.П., Пономарчук В.А. Венд-раннекембрийский островодужный плагиогранитоидный магматизм Алтае-Саянской складчатой области и Озерной зоны Западной Монголии (геохронологические, геохимические и изотопные 
данные) // Геология и геофизика, 2013, т. 54, № 10, с. 1628-1647.

Руднев С.Н., Серов П.А., Киселева В.Ю. Венд-раннепалеозойский гранитоидный магматизм Восточной Тувы (геохронологические, геохимические и Sr-Nd изотопные данные) // Геология и геофизика, 2015, т. 56 (9), с. 1572-1600.

Руднев С.Н., Мальковец В.Г., Белоусова Е.А., Третьякова И.Г., Гибшер А.А. Состав и возраст плагиогранитоидов южной части Озерной зоны Западной Монголии // Геология и геофизика, 2019, т. 60 (11), с. 1513-1541.

Руднев С.Н., Мальковец В.Г., Белоусова Е.А., Туркина О.М., Семенова Д.В. Изотопный Lu-Hf состав циркона и источники магм венд-раннепалеозойских гранитоидов Тувы (на примере Каахемского и Восточно-Таннуольского батолитов) // Геология и геофизика, 2020, т. 61, (в печати).

Скляров Е.В., Гладкочуб Д.П., Мазукабзов А.М., Меньшагин Ю.В., Константинов К.М., Ватанабе Т. Дайковые рои южногофланга Сибирского кратона индикаторы распада суперконтинента Родиния // Геотектоника, 2000, № 6, с. 59-75.

Терентьева Л.Б., Козаков И.К., Ярмолюк В.В., Анисимова Л.В., Козловский А.М., Кудряшова Е.А., Сальникова Е.Б., Яковлева С.3, ФедосеенкоА.М., Плоткина ю.В. Конвергентные процессы в эволюции Ранних каледонид Баян-Хонгорской зоны Центральной Азии: геологические и геохронологические исследования Хан-Улинского габброидного плутона // Доклады АН, 2010, т. 433 (2), с. 237-243.

Федотова А.А., Хаин Е.В. Тектоника юга Восточного Саяна и его положение в Урало-Монгольском поясе. М.: Научный мир, 2002, 176 с.

Хаин Е.В., Амелин Ю.В., Изох А.Э. Sm-Nd данные о возрасте ультрабазитбазитовых комплексов в зоне субдукции Западной Монголии // Доклады АН, 1995, т. 341 (6), с. 791-796.

Хубанов В.Б., Буянтуев М.Д., Цыганков А.А. U-Pb изотопное датирование цирконов из PZ3-MZ магматических комплексов Забайкалья методом магнитно-секторной масс-спектрометрии с лазерным пробоотбором: процедура опрерделения и сопоставления с SHRIMP-II данными // Геология и геофизика, 2016, т.57 (1), с. 5-25.

Ярмолюк В.В., Коваленко В.И. Позднерифейский раскол Сибири и Лаврентии в проявлениях внутриплитного магматизма // Доклады АН, 2001, т. 379 (1), с. 94-98.

Ярмолюк В.В., Коваленко В.И., Ковач В.П., Рыцк Е.Ю., Козаков И.К., Котов А.Б., Сальникова Е.Б.. Ранние стадии формирования Палеоазиатского океана: результаты геохронологичесих, изотопных и геохимичесих исследований позднерифейских и вендкембрийских комплексов Центрально-Азиатского складчатого комплекса // Доклады АН, 2006, 410 (5), c. 657-662. 
Ярмолюк В.В., Коваленко В.И., Анисимова И.В., Сальникова Е.Б., Ковач В.П., Козаков И.К., Козловский А.М., Кудряшова Е.А., Котов А.Б., Плоткина Ю.В., Терентьева Л.Б., Яковлева С.3. Позднерифейские щелочные граниты Дзабханского микроконтинента: к оценке времени распада Родинии и формирования микроконтинентов Центрально-Азиатского складчатого пояса // Доклады АН, 2008, т. 420 (3), с. 375-381.

Ярмолюк В.В., Ковач В.П., Коваленко В.И., Сальникова Е.Б., Козловский А.М., Котов А.Б., Яковлева С.З., Федосеенко А.М. Состав, источники и механизмы формирования континентальной коры Озерной зоны каледонид Центральной Азии: I. Геологические и геохронологические данные // Петрология, 2011, т. 19 (1), с. 83-107.

Buriánek D., Schulmann K., Hrdličková K., Hanžl P., Janoušek V., Gerdes A., Lexa O. Geochemical and geochronological constraints on distinct EarlyNeoproterozoic and Cambrian accretionary events along southern margin of the Baydrag Continent in western Mongolia // Gondwana Research, 2017, 42, p. 200-227.

Dijkstra, A.H., Brouwer, F.M., Cunningham, W.D., Buchan, C., Badarch, G., Mason, P.R.D. Late Neoproterozoic proto-arc ocean crust in the Dariv Range, Western Mongolia: a supra-subduction zone end-member ophiolite // J. Geol. Soc., 2006, v. 163, p. 363-373.

Frost B.R., Barnes C.G., Collins W. J., Arculus R.J., Ellis D.J., Frost C.D. A geochemical classification for granitic rocks // Journal of Petrology, 2001, 42, p. 2033-2048.

Geological map of Mongolia. (Ed.), O. Tomurtogoo. General Directorate of Min. Res and Explor. of Turkey, Ankara, 1999.

Gibsher A.S., Perelyaev V.I., Rayabinin A.B. The structure of Vendian oceanic crast (Western Mongolia, Suvra-Gol). // Structural and Tectonic Correlation across the Central Asia Orogenic Collage: Implications for Continental Growth and Intracontinental Deformation (Abstracts and Excursion Guidebook). 2006, Ulaanbaatar, Mongolia, p. 86-87.

Janoušek V., Jiang Y., Buriánek D., Schulmann K., Hanžl P., Soejono I., Kröner A., Altanbaatar B., Erban V., Lexa O., Ganchuluun T., Košler J. Cambrian-Ordovician magmatism of the Ikh-Mongol Arc System exemplified by the Khantaishir Magmatic Complex (Lake Zone, south-central Mongolia) // Gondwana Research, 2018, v. 54, p.122-149.

Jian P., Kröner A., Windley B.F., Shi Y., Zhang F., Miao L., Tojurhuu D., Zhang W., Liu D. Zircon ages of the Bayankhongor ophiolite mélange and associated rocks: time constraints on Neoproterozoic to Cambrian accretionary and collisional orogenesis in Central Mongolia // Precambrian Research, 2010, 177, p. 162-180.

Jian P., Kröner A., Jahn B.-M., Windley B.F., Shi Y., Zhang W., Zhang F., Miao L., Tomurhuu D., Liu D. Zircon dating of Neoproterozoic and Cambrian ophiolites inWest 
Mongolia and implications for the timing of orogenic processes in the central part of the Central Asian Orogenic Belt // Earth-Science Reviews, 2014, 133, p. 62-93.

Khain E.V., Kroner A., Gibsher A.S., Fedotova A.A. The fate of Rodinia in the light of the discovery of ca. 1000 Ma old ophiolites in the Central Asian orogenic belt of Siberia. // Gondwana Res., 2001, v. 4, p. 656-658.

Khain E.V., Bibikova E.V., Salnikova E.B., Kroner A., Gibsher A.S., Didenko A.N., Degtyarev K.E., Fedotova A.A. The Palaeo-Asian ocean in the Neoproterozoic and early Palaeozoic: new geochronologic data and palaeotectonic reconstructions // Precambrian Research, 2003, v. 122, p. 329-358.

Khukhuudei U., Kusky T., Otgonbayar O., Wang L. The Early Palaeozoic megathrusting of the Gondwana-derived Altay-Lake zone in western Mongolia: implications for the development of the Central Asia orogenic belt and Paleo-Asian ocean evolution // Geological Journal, 2020 (in press).

KrönerA., Tomurtogoo O., Badarch G., Kozakov I.K. New zircon ages and significance for crustal evolution in Mongolia // Ed. Skiyariv E.V. Assembly and Break-up of Rodinia Supercontinent: Evidence from South Sibiria. Guidebook and abstract volume. Workshop IGCP-440. Irkutsk, 2001, p. 142-145.

Le Maitre R. W. A. Classification of Igneous Rocks and Glossary of Terms: Recommendations of the International Union of Geological Sciences, Subcommission on the Systematics of Igneous Rocks. Oxford: Blackwell., 1989, 193 p.

Levashova N.M., Kalugin V.M., Gibsher A.S., Jessica Yff, Ryabinin A.B., Meert J.G., Malone S.J. The origin of the Baydaric microcontinent, Mongolia: Constraints from paleomagnetism and geochronology // Tectonophysics, 2010, v. 485, p. 306-320.

Maniar P.D., Piccoli P.M. Tectonic discrimination of granitoids // Geological Society of America, Bullutin, 1989, 101, p. 635-643.

Meert J.G., Torsvik T.H. The making and unmaking of a supercontinent: Rodinia revisited // Tectonophysics, 2003, v. 375, p. 261-288.

O’Connor J.T.A. A classification for quartz-rich igneous rock based on feldspar ration // U.S. Surv., Prof. Paper., 1995, 52B, B79-B84.

Pfänder J.A., Jochum K.P., Kozakov I.K., Kröner A., Todt W. Compled evolution of back-are island arc-like vafic crust in the late-Neoproterozoic Agardag Nes-Chem ophiolite, Central Asia: evidence from trace element and Sr-Nd-Pb isotopic data // Contrib. Mineral. Petrol., 2002, v. 143, p. 154-174.

Rickwood P.C. Boundary lines within petrologic diagrams which use oxides of млн летjor and minor elements // Lithos, 1989, 22, p. 247-263. 
Samozvantsev B.A., Tsukernik A.B., Golyakov B.I., Baatarkhuyag F. Results of 1:200 000 scale geological mapping and general prospecting in Great Lakes depression of western branches of Hangay Highland. Ulaanbaatar. Information center open-file report \#3576, 1981, $1036 \mathrm{p}$.

Torsvik T.H., Smethurst M.A., Meert J.G., Van der Voo R., McKerrow W.S., Brasier M.D., Sturt B.A., Walderhaug H.J. Continental break-up and collision in the Neoproterozoic and Paleozoic -a tale of Baltica and Laurentia // Earth Sci. Rev., 1996, v. 40 (3-4), p. 229-258.

Watanabe T., Postnikov A.A., Ota T., Maehara K., Agashev A., Morita T., Roser B.P. Kuvai Group volcanic rocks (Riphean) in the Beret area, Sayan Mountains, SW Siberia. A study of the Paleo-Asian Ocean. // Special Reports on the Regional Studies of North-East Eurasia and North Pasific in Hokkaido University. 1999, p. 103-112. 


\section{Подписи к рисункам}

в статье Руднев С.Н., Гибшер А.С., Семенова Д.В.

“Вендский островодужный интрузивный магматизм Озерной зоны Западной Монголии (геологические, геохронологические и петрохимические данные) ”

Рис. 1. Современная структура Центрально-Азиатского подвижного пояса [по Гибшер, 2017].

I-IV - блоки фундамента Центрально-Азиатского микроконтинента (I - Байдарикский массив, II - Тарбагатайский массив, III - Гарганский массив, IV - Канский массив).

Рис. 2. Тектоно-стратиграфический разрез океанической коры и вендского островодужного комплекса Хантайширского окраиноморского бассейна [по Gibsher et al., 2006 с дополнениями]. Белый круг - U-Pb даты по цирконам из даек толеитовых

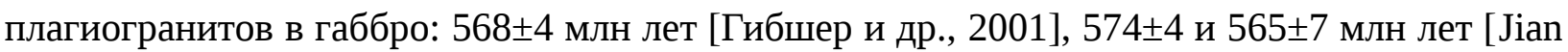
et al., 2014].

Рис. 3. Схематическая геологическая карта Озерной структурно-формационной зоны Западной Монголии (составлена с упрощениями и дополнениями, на основе данных [Geological ...,1999; Руднев и др., 2009, 2012, 2019; Samozvantsev et al., 1981]).

1-6 - стратифицированные образования: 1 - Центрально-Азиатский микроконтинент (ЦАМ), 2-3 - Озерная структурно-формационная зона: 2 - вендские островодужные осадочно-вулканогенные комплексы (нерасчлененные), 3 раннекембрийские островодужные осадочно-вулканогенные комплексы (нерасчлененные); 4 - ранне-среднепалеозойские аккреционные комплексы Монгольского Алтая (нерасчлененные), 5 - среднепалеозойские осадочные и вулканогенные комплексы (нерасчлененные); 6 - мезо-кайнозойские отложения (нерасчлененные); 7-13интрузивные образования: 7 - неопротерозойские офиолитовые комплексы (нерасчлененные), 8-9 - интрузивные комплексы вендского возраста (8 - габброиды, 9 гранитоидны), 10-11 - интрузивные комплексы раннего кембрия (10 - габброиды, 11 гранитоиды), 12 - интрузивные комплексы позднего кембрия-ордовика (нерасчлененные), 13 - интрузивные комплексы девона (нерасчлененные); 14 - тектонические нарушения. 15 - результаты U-Pb изотопного датирования цирконов (цифрами показаны значения возрастов в млн лет). В круглых скобках даны номера и названия массивов и плутонов: 1 Шаратологойский, 2 - Западно-Баян-Хаирханский, 3 - Харанурский, 4 - Шутхуинский, 5 Дарви, 6 - Бумбат-Хаирханский, 7 - Три Холма, 8 - Таван-Хаирханский, 9 - ВосточноБаянцаганский, 10 - Баян-Цаган-Ула, 11 - Баясгалантский, 12 - Тунгалагский, 13 - Хатан- 
Хунгинский, 14 - Тугригский, 15 - Удзур-Хунгинский, 16 - Их-Замынский, 17 - офиолиты хр. Дариби, 18 - офиолиты хр. Хан-Тайшири, 19 - массив в южных отрогах хр. ХанТайшири [Buriánek et al., 2017].

На врезке показана схематическая тектоническая карта Западной Монголии. Докембрийские микроконтиненты: ЦА - Центрально-Азиатский, ЮГ - Южно-Гобийский; ОЗ - островодужная система Озерной зоны (венд - ранний кембрий); аккреционные комплексы (ранний-средний палеозой): МА - Монголо-Алтайский, ЮМ - ЮжноМонгольский. Звездочкой красного цвета, показано положение массивов плагиогранитоидов и габброидов вендского возраста, звездочкой желтого цвета раннекембрийского возраста.

Рис. 4. Катодолюминесцентные изображения зерен циркона из пород вендских интрузивных ассоциаций Озерной зоны. Кружком показаны точки, где проводились U-Pb изотопные исследования магматического и ксеногенного циркона, цифрами показаны значения возрастов (в млн лет). Результаты анализов см. табл. S1, S2.

Проба С-5-66.3 - массив Три Холма (плагиогранит), проба PM-35/1-07 - ТаванХаирханский массив (лейкогаббро), проба РМ-10-47 - Восточно-Баянцаганский массив (плагиогранит), проба РМ-44/1-07 - массив Баян-Цаган-Ула (тоналит-порфир), проба РМ7-16 - Тунгалагский массив (плагиогранит, ранний ритм), проба РМ-8-15 - Тунгалагский массив (плагиогранит, поздний ритм), проба РМ-13А-16 - Их-Замынский массив (гранит), проба РМ-81-18 - Шутхуинский массив (кварцевый диорит).

Рис. 5. Диаграммы с конкордиями для цирконов изученных массивов.

На диаграммах серыми эллипсами показаны возрасты ксеногенного циркона, остальные отвечают возрастам магматического циркона. Результаты анализов см. табл. S1, S2.

Рис. 6. Дискриминационные диаграммы для пород изученных интрузивных ассоциаций: $\mathrm{SiO}_{2}-\mathrm{K}_{2} \mathrm{O}+\mathrm{Na}_{2} \mathrm{O}$ диаграмма по [Le Maitre, 1989]; $\mathrm{SiO}_{2}-\mathrm{K}_{2} \mathrm{O}$ диаграмма по [Rickwood, 1989]; SiO2-FeOtot/(FeOtot + MgO) диаграмма по [Frost et al., 2001]; A/CNK-A/NK диаграмма по [Maniar, Piccoli, 1989]; Ab-An-Or диаграмма по [O’Connor, 1965]. А тоналит, В - гранодиорит, C - адамеллит, D - трондьемит, E - гранит. Анализы пород см. табл. S3.

1 - диорит-тоналит-плагиогранитная ассоциация массива Три Холма, 2 - габброиды Таван-Хаирханского массива, 3 - плагиогранитная ассоциация Восточно-Баянцаганского массива, 4 - диорит-тоналит-плагиогранитная ассоциация массива Баян-Цаган-Ула, 5-6 - 
плагиогранитоидные ассоциации Тунгалагского массива (5 - ранний ритм, 6 - поздний ритм), 7 - диоритовая ассоциация Шутхуинского массива, 8 - гранитная ассоциация ИхЗамынского массива. 
Терригенные породы и известняки с мелкораковинной фауной томмотского яруса нижнего кембрия

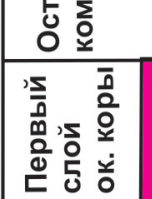

$+$

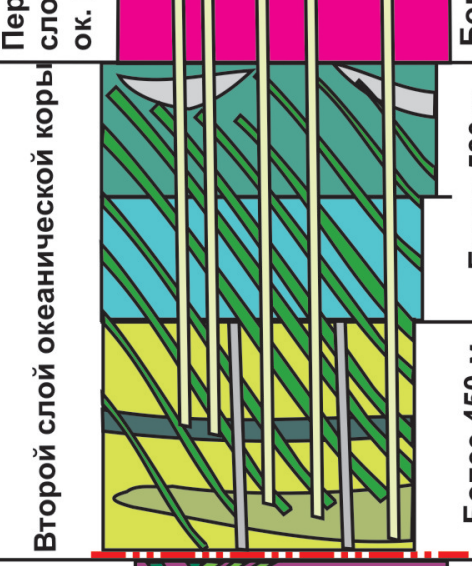

Верхние лавы.

Шаровые, пузыристые лавы спилитов, базальтовых андезитов, андезитов и андезито-дацитов, гиалокластиты, и дайки - подводящие каналы.

Породы отвечают известковощелочной и толеитовой серии.

\section{Тонкослоистые кремнистые}

турбидитовые осадки, линзы об̆ломочных пород деб̄рисных потоков

Нижние лавы.

Трубообразные, шаровые и массивные лавы высоко-магнезиальных андезитов и андезибазальтов (бонинитов), комплекс типа дайка в дайке с боннинитовыми характеристиками. Скрины амфиболизированных, окварцованных лав, габброидов, пироксенитов.

Пакеты субширотных диабазовых даек \begin{tabular}{l|l}
$\Sigma$ & с односторонней закалкой (на юг). \\
$\&$ & В скринах измененные диабазовые дайки
\end{tabular} ๖ субмередианального простирания, ¿ диоритовые порфириты (силлы) и 을 апоабро-диориты и амфиболовые габбро (верхние магматические камеры).

В скринах пироксенсодержашие дайки, плагиогранофиры, диориты,массивные лейко-, мезо- и меланократовые габбро, меланогаббро, пироксениты и дуниты расслоенной кумулятивной серии. Белый круг - U-Pb дата 568 +/-4 Ма по цирконам из плагиогранитов.

Кумулятивный ритмично слоистый дунит-пироксенит-габбровый разрез с жилами и дайками плагиогранофиров и диабазов. Рама магматических камер - апооливинитовые и аподунитовые серпентиниты. Аподунитовые и апогарцбургитовые деформированные гипербазиты. 

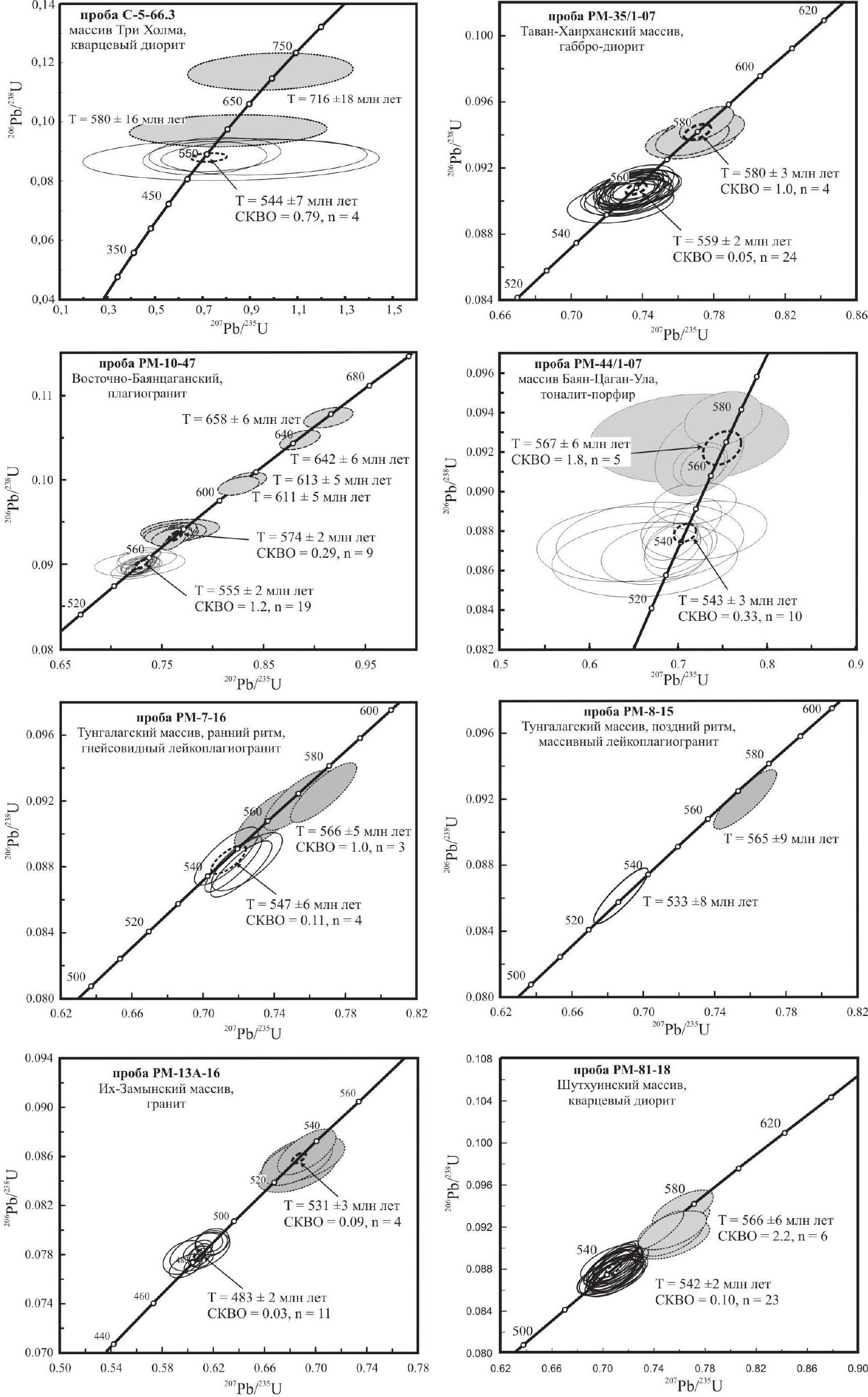

рис. 5 
